\title{
Traditional Market Issues
}

\author{
Suryanto \\ Department of Business Administration \\ Univeristas Padjadjaran \\ Bandung, Indonesia \\ suryanto@unpad.ac.id
}

\author{
Bambang Hermanto \\ Department of Business Administration \\ Universitas Padjadjaran \\ Bandung, Indonesia \\ b.hermanto@unpad.ac.id
}

\author{
R. Meisa Dai \\ Department of Business Administration \\ Universitas Padjadjaran \\ Bandung, Indonesia \\ lexsa_dai@yahoo.com
}

\begin{abstract}
This study aims to determine the problems faced by traditional markets in Pangandaran Regency, West Java Province, Indonesia. Primary data sources are obtained from observation, results of in-depth interviews and focus group discussions, while secondary data is obtained from the results of compilation and processing of data in the form of research results, scientific articles, and documents related to the object of this study. The results show that the problems that occur in traditional markets in Pangandaran Regency are caused by several aspects. The aspects include management of traditional markets, mechanisms for licensing the establishment of modern markets, socio-cultural aspects, and the role of local governments in managing traditional markets. The aspects of traditional marketing management have been managed by regional organs (OPD) which have to manage more than one market so that there is limited managerial ability. Aspects of the licensing mechanism for the occurrence of several violations in issuing permits and licensing supervision systems. Socio-cultural aspects related to the behavior of traders who have not been able to present their merchandise in quality and orderly. While the aspect of the role of the regional government is related to the provision of market facilities and infrastructure, cleanliness and order, management of retribution, as well as fostering socio-cultural aspects.
\end{abstract}

Keywords - traditional market, management, licensing, socio-cultural, government role

\section{INTRODUCTION}

Traditional market business activities are known in the community since time immemorial. However, in the last few decades activity in traditional markets has begun to change since the emergence of modern markets. The emergence of a modern market, according to Reardon \& Hopkins (2006) due to the deregulation of the retail business sector which aims to increase foreign direct investment.

Reardon, et.al (2003) found that since 2003 modern market share in the retail business sector in several developing countries such as South Korea, Thailand, Taiwan, Mexico, Poland, and Hungary has reached $50 \%$. While in Brazil and Argentina, where the development of the modern market has already begun, the market share reaches around $60 \%$.

Local modern markets in Indonesia have been around since the 1970s, although they are still concentrated in big cities. The modern foreign-brand market began to enter Indonesia in the late 1990s, since the foreign direct investment policy in the retail business sector opened in 1998.
The presence of a modern market in Indonesia initially only served the upper middle class (CPIS, 1994). However, in its development, the modern market extends to small cities and serves to lower middle-class consumers. This problem is certainly also experienced in other developing countries (Reardon et al 2003; Collett \& Wallace 2006).

Problems began to arise when modern markets began to enter the existence of traditional markets. Aggressive expansion for the establishment of this modern shopping center has been licensed by the relevant Regional Government where the process of granting permits by local authorities is not carried out transparently and often collides with various personal interests within it.

Competition between traditional markets and modern markets is a logical consequence that arises with the presence of modern markets that compete for the same products and consumers. Modern markets that are supported by modern management and comfortable physical facilities and certainty of prices are the main attraction for consumers. This is in accordance with the findings of Daniel, et al. (2007) that the main cause of the loss of competing for traditional markets with modern markets is weak management and poor traditional market infrastructure, not solely because of the existence of supermarkets. Supermarkets actually take advantage of the bad conditions in traditional markets.

Although competition theoretically benefits consumers, but has an impact on the development of traditional markets and the economy as a whole. Although the development of the modern market has become more intense, it seems that some people still have and have a culture to keep shopping at traditional markets. This happens because in the traditional market, there is still a price bargaining process, whereas in the modern market the price is definitely marked with a price tag (Hermanto, Suryanto, and Dai, 2018).

Research on traditional markets and modern markets have been carried out by several researchers. Rinda (2014) concludes that the development of modern markets has resulted in traditional markets becoming increasingly marginalized. The results of the same research according to Purnama and Yasa (2013) show that the growth of modern markets is very troubling for traders in traditional markets which will eventually turn off traditional markets.

While according to research conducted by Wiboonpongse and Sriboonchitta (2006) traditional markets are underdeveloped because of the minimal carrying capacity of traditional traders. Another factor that causes traditional markets to be underdeveloped according to Tambunan, et al. (2004) because the distribution chain is relatively longer. The longer the distribution chain adds to the expensive items to 
be sold. This is different from what modern retailers do, they have a fairly short distribution channel so that it can reduce the selling price. This difference in distribution channels results in price differences between traditional and modern retail, which causes the weak competitiveness of traditional markets to modern markets.

Other research results according to Hermanto, Suryanto, and Dai (2018) conclude that the modern market is managed professionally with a business approach. A more centralized modern market management system that allows the master manager to manage the standard of business management. While in traditional markets, institutional management is part of the bureaucratic system.

Some of the factors that need to be studied in the retail industry are regulatory factors, product efficiency factors, and economics of scope, location factors, consumer behavior factors including patterns of people's consumption tastes and characteristics of products sold.

\section{Methodology}

\section{A. Selecting a Template (Heading 2)}

The method used in this study is a qualitative research method with a descriptive approach. Descriptive research as described by Koentjaraningrat (1997) aims to describe precisely the characteristics of an individual, circumstances, symptoms, or certain groups. Denzin and Lincoln (1994) describe that the choice of this method is chosen to get a fundamental understanding through the first-hand experience of researchers who directly process and fuse into one part that is inseparable from the subject and setting to be studied.

The main source of information that will be a reference to the data and information in this study consists of primary and secondary sources. Primary sources are obtained from the process of in-depth interviews, focused discussions, and direct observation in the field. The secondary data sources were obtained and collected from the results of compilation and processing of data in the form of research results, scientific articles, publications, and documents related to the object of this study. Primary data are obtained through observation, interviews and focus group discussions (FGD).

Data that has been collected from the research process will then be analyzed by descriptive analysis. Suryabrata (1993) states that descriptive analysis is intended to make descriptions of situations or events. An overview or information about an event or object that arises from a field note is assessed while still considering the degree of internal coherence, making sense, and relating to factual and realistic events. The qualitative data analysis process includes testing, selecting, categorizing, evaluating, comparing, synthesizing, and reflecting on the data that the researcher obtained to build inferences and then draw conclusions so that a holistic understanding is achieved.

\section{RESULTS AND DISCUSSION}

Traditional markets in Pangandaran Regency consist of two groups, namely traditional markets managed by the district government and traditional markets managed by the village government. There are three traditional markets managed by the district government, namely Pananjung Market, Parigi Market, and Kalipucang Market. While there are 24 traditional markets managed by the village government in 10 sub-districts.
The existence of traditional markets began to experience problems since the presence of the modern market. The modern market in Pangandaran Regency is in the form of modern shops spread across 9 districts. There are 50 modern shops, consisting of Indomaret, Alfamart, Yomart, Kuckmart, and Srikaton. The most widespread distribution of modern stores is in Pangandaran District, while the subdistrict where there is no modern shop is Langkaplancar District.

The problems that arise related to traditional market can be seen from several aspects, including (1) management of traditional markets, (2) mechanisms for licensing the establishment of modern markets, (3) socio-cultural aspects, and (4) the role of local governments in managing traditional markets.

\section{A. Management of Traditional Markets}

Traditional market conditions in Pangandaran District, both managed by the district government and those managed by the village government face relatively the same problems. The problem is that there are kiosks and stalls that are not filled with traders. The traders do not want to fill kiosk and kiosk units due to several factors, including: (1) many traders who come out to become street vendors because they are more accessible to buyers; (2) The retribution of traders selling at the kiosks is greater than the PKL fees; and (3) the location of the kiosks is less strategic.

The emergence of street vendors around traditional markets is a rival for traditional market traders who sell in the market. Based on empirical experience conducted by SMERU (2007) obtained information that one of the main competitors of traders in traditional markets as street vendors. They sell to cover the front and the entrance to the market so that the outside of the traditional market looks shabby and chaotic. Conditions like this are always left by traditional market managers without a solution. On average, buyers do not look for items they are looking for in the market, they trade with street vendors on the front of the traditional market or on the side of the road. As a result, traders in the traditional market become quiet.

To avoid competition in market traders with street vendors, it is actually not complicated. The government and managers of traditional market traders need to make arrangements by placing the street vendors to the specified location. The placement of PKL locations should no longer cause new slums and not compete with traditional market traders.

The arrangement of traditional market traders and street vendors should be carried out under one regional work unit (OPD). However, considering that the OPD is not only responsible for fostering traders, but also fostering other business actors, the development of traditional market traders becomes less focused. Moreover, in practice, traditional market management involves the authority of other agencies, such as in the fields of parking, cleanliness, security, and order, health, environment, consumer protection, and meteorological (orderly measurement). Likewise, many parties are involved in the arrangement and guidance of street vendors, such as those related to territorial structuring, security and order, cleanliness, and retail trade.

Often the Heads of OPD have limited authority in managing traditional markets. One of them is in the face of 
the officers who are under the control of other OPD outside the OPD in charge of markets and traders, such as officers who handle parking, cleanliness and landscaping, construction and maintenance of facilities and infrastructure, and also sometimes handling order PKL. Here the role of supervisory OPD is very necessary to coordinate with other relevant DPOs.

Handling the problems of traditional market traders and street vendors is the most ideal when handled by OPD specifically. The OPD in the structure, there are fields that handle traditional markets including street vendors. The Head of Division who handles Traditional Markets and the Head of Division who handles PKL can coordinate with each other in handling these two groups of traders.

During this time the Head of OPD often supervised several traditional market management, without any special people managing each of these markets. This results in a limited managerial ability in managing the market. The negative stigma attached to traditional markets, in general, is one of the results of the managerial ability.

Based on empirical experience, traditional markets that have a high level of cleanliness, safety and comfort usually have a Market Management Team with a complete organizational structure with clear and fairly detailed work guidelines. In addition, the market manager is also intensively fostered and supervised by OPD in charge of traditional markets and traders.

In some cities, traditional market management organizations are in the form of Regional Companies. Regional companies usually have better management capabilities than traditional market management parties under OPD in charge of the market.

\section{B. Giving Permit to Establish Modern Markets}

Modern markets in Pangandaran Regency are only Modern Stores. The number of modern shops totaling 50 stores turns out that there are some who do not have licenses or are still illegal. The permit includes Disturbance Permit (HO), Modern Store Business Permit (IUTM), and Company Registration Sign (TDP). Therefore, the modern store has violated Regional Regulation No. 9 of 2015 concerning the Implementation of Licensing, Pangandaran Regent's Regulation Number 27 of 2015 concerning the Control of Modern Stores and Protection of Small Businesses, Stalls / Shops and Traditional Markets, and Regent Regulations No. 35 of 2016 concerning Moratorium or Dismissal While Giving Modern Store Permit in Pangandaran Regency.

When referring to the Regent's Regulation Number 27 of 2015 , violations or compromises have been found in several articles. Most violations are related to the location of the establishment of a modern store that is facing each other, side by side or adjacent to a traditional market. Here it was found that the regulations that had been made could be violated because of a compromise with local market traders or sub-district and village governments. Compromises like this cause modern market locations to be concentrated in crowded centers, namely near markets, squares or government offices. Conditions like this certainly have the potential to have a negative impact on traditional markets and small traders.
Likewise, regulations regarding the operating hours of modern stores are still widely violated or compromised for certain reasons. Regulations regarding store operating hours, especially outside tourist destinations, should be strictly implemented so as not to have a negative impact on traditional markets and small traders.

Modern market licensing in Pangandaran Regency is the responsibility of the Integrated Licensing Service and Investment Agency (BPPTPM). In granting permission for the establishment of a modem market must be in accordance with the regulations in Pangandaran Regency. In its implementation, BPPTPM did not run on its own, but supported by other stakeholders, for example, the Pramong Praja Police Unit on the control section. Even the two parties, namely between BPPTPM and the Pramong Praja Police Unit blamed each other for the rampant illegal modern shops that were still operating.

Actually, the licensing mechanism in establishing a modern market in Pangandaran Regency is good. This can be seen from the regulations related to the construction of a modern market that has considered various important aspects, such as the distance between traditional markets, the distance between modern shops, the limit of the population for a modern store, and so on. The implementation of the mechanism is not carried out properly by the authorities. Thus, there is a need for seriousness, firmness, and good coordination from all parties concerned.

\section{Socio-cultural}

Aspect socio-culture illustrates that the level of awareness of market trading is to improve the quality of hygiene, clean and neat quality, quality of services and health of goods and services offered. The OPD of the market manager is doing waste management with waste disposal methods, but this is not supported by the awareness and compliance of the trade. Other than that, the trading behavior that is still often found in the display of goods that are in the same way. Supposedly the habit of being changed is changed to the merchant's stall, that is, by paying attention to the merchandise being neatly arranged and keeping it safe so that it attracts consumers to the business. The neat arrangement of merchandise makes it easy for sales transactions because it is easy to find items that are desired by consumers. But the practice, the level of awareness and caring of the traders in terms of the poor and the comfort of the market is still very lacking.

Market consumer satisfaction is also influenced by the quality factor of merchandise, where market traders are still not paying attention to qualities such as the freshness of vegetables, the safety of color substances, and so on. Because of that. It is necessary to develop development and standardize the quality of products/commodities on a scaleby-scale basis for the traders in order to increase the public's trust in traditional markets. This is because competitiveness does not always focus on prices, but also on sales services.

Based on social and cultural problems that cover traditional markets, traditional market trading needs to be fostered and obtain information about the future, threats and business opportunities. And the need to change attitudes and business practices, according to changes in consumer demands. 


\section{The Role of the Government of Pangandaran Regency}

Regional autonomy is expected to make the government even closer, understand and understanding the community so that the function as a facilitator can work well (Ismawan, 2003). In carrying out traditional market policies and activities, the Pangandaran District Government assigns tasks to certain OPDs.

The OPD in managing traditional markets refers to the existing regulations, including: Ministry of Home Affairs Number 20 of 2012 concerning Management and Empowerment of Traditional Markets; Regional Regulation No. 9 of 2015 concerning Implementation of Licensing, Pangandaran Regent's Regulation Number 27 of 2015 concerning Control of Modern Stores and Protection of Small Businesses, Stalls / Shops and Traditional Markets, and Regent Regulations No. 35 of 2016 concerning Moratoriums or Termination While Giving Modern Stores Pangandaran Regency.

Regarding the role of the district, the government is divided into four important aspects, namely market facilities and infrastructure, cleanliness and order, management of retribution, and fostering socio-cultural aspects. The availability and maintenance of market facilities and infrastructure are carried out by the Market Management Sector. Actually, the government has developed a waste segregation program in traditional markets, namely dry waste and wet waste or organic and non-organic waste. However, this is not supported by traders. Another means is the facilitation of market cooperatives. Cooperatives that are available at Pasar Pananjung, Parigi Market, and Markets are only in the form of an indoor building. The cooperative is not maintained and is not operated by the traders, even though the traders really expect a cooperative facility.

OPD has full authority in terms of managing market cleanliness and order. They can cooperate with other parties or institutions. This critical phenomenon which needs attention is evident in markets managed by the district government and markets managed by the village government. Based on the facts on the ground, traditional markets in Pangandaran Regency have not fulfilled market aspects. According to the market manager, it was stated that one of them was caused by a lack of human resources (HR). The availability of infrastructure tools and facilities for infrastructure is not matched by adequate human resources. In the policy related to order, the traditional markets in Pangandaran Regency are still not maximal in its implementation. This is seen in the presence of mushrooming street vendors (PKL), especially in areas around the market.

Money market service fees collected from traders are managed and used for market needs and needs, such as infrastructure. In its application, OPD adjusts the use of retribution by looking at the needs in the field. The collection of levies for each market varies according to the level of need. In the system of administering market service fees, withdrawal or collection of levies is carried out by the respective UPT markets. Each UPT set a retribution target at the beginning of the year and reports on retribution until the end or closes the year.

So far the traditional market is only considered as a contributor to income through collected fees. The district government tightened the implementation of retribution collection so as to achieve the target set, but this was not balanced with the improvement of the quality of the traditional market itself, especially in terms of the physical building on the market. Traditional market conditions that have been synonymous with the slum, squalid and crowded conditions. Whereas through such fees, it can at least help improve market management.

\section{CONCLUSION}

Problems related to traditional markets can be seen from several aspects, including: managing traditional markets, granting permission to establish modern markets, sociocultural aspects, and the role of local governments.

Stalls in many traditional markets are closed because of a number of things, including (1) many traders who go out to become street vendors are more accessible to buyers; (2) The retribution of traders selling at kiosks is greater than the PKL fees; and (3) the location of the kiosks is less strategic. These problems occur because of the market manager, in this case, the Head of OPD has limitations having to manage several traditional markets.

The rules that underlie the modern market licensing mechanism in Pangandaran Regency are actually quite good. That is for the Minister of Home Affairs regulations, regional regulations, and regent regulations. However, in its implementation, the district government has not optimally carried out the regulation. There are several modern markets that are unlicensed, the distance between modern markets, and modern market operating hours. There needs to be assertive and coordinated from the parties involved in solving this problem, from licensing to enforcement.

Based on cultural aspects, traders in traditional markets were not able to have good behavior in preparing goods and arranging goods to be sold. They have not been able to prepare goods both in terms of quality and hygiene, clean and neat, as well as the cleanliness of the place and the health of the goods and services offered. The arrangement of the items to be sold is still unclear, so that consumers cannot directly sell what items are sold on the place.

The role of local governments in dealing with traditional market issues is divided into four important aspects, namely market facilities and infrastructure, cleanliness and order, management of retribution, as well as fostering socio-cultural aspects.

\section{REFERENCES}

[1] Hermanto, Suryanto, dan Dai, 2018, Identification of Traditional Market Characteristics and Modern Markets in Pangandaran District, West Java Province, Indonesia, Advanced Science Letters, Volume 24, Number 1, January 2018, pp. 365-368(4)

[2] Collett, P \& Tyler, Wallace. 2006. Background Report: Impact of Supermarkets on Traditional Markets and Small Retailers in The Urban Centers. Mimeo. Jakarta: Smeru Research Institute

[3] CPIS. 1994. Perdagangan Eceran di Indonesia: Skala Kecil vs Skala Besar. Jakarta: Center for Policy and Implementation Studies.

[4] Daniel Suryadarma, Adri Poesoro, Sri Budiyati, Akhmadi, dan Meuthia Rosfadhila, 2007. Dampak Supermarket terhadap Pasar dan Pedagang Ritel Tradisional di Daerah Perkotaan di Indonesi, SMERU Laporan Penelitian.

[5] Denzim and Lincoln. 1994, Hand Book of Qualitative Research, Sage Publication, Thousan Oaks, London, 136-37. 
[6] Ismawan, Bambang. 2003. Partisipasi dan Dimensi Keswadayaan: Pengalaman LSM Membangun Keswadayaan Masyarakat. Dalam Http//www. Ekonomirakyat.org/edisi15.

[7] Koentjaraningrat. 1997. Metode-Metode Penelitian Masyarakat. Jakarta: PT.Gramedia Pustaka Utama

[8] Purnama, Ida Ayu Made Sherly Purnama dan I Nyoman Mahaendra Yasa. 2013. Faktor-faktor yang Mempengaruhi Keputusan Wisatawan Domestik Berbelanja Di Pasar Oleh-Oleh Modern EJurnal EP Unud. Vol.2 No. 5, pp: 244-253.

[9] Reardon, Thomas, C. Peter Timmer, Christopher B. Barrett, and Julio Berdegué. 2003. The Rise of Supermarkets in Africa, Asia, and Latin America' American Journal of Agricultural Economics, 85(5).

[10] Reardon, Thomas and Rose Hopkins . 2006. The Supermarket Revolution in Developing Countries: Policies to Address Emerging Tensions among Supermarkets, Suppliers, and Traditional Retailers. European Journal of Development Research, 18(4).
[11] Rinda, 2014. Peran Modal Sosial Terhadap Eksistensi Pasar Tradisional. Jurnal Ilmiah Mahasiswa FEB Universitas Brawijaya. Vol.2 No.2.

[12] Suryabrata Sumadi. 1993. Psikologi Pendidikan. Jakarta. PT. Raja Grafindo Persada.

[13] Tambunan TH, .Nirmalawati D, dan Silondae AA. 2004. Kajian Persaingan dalam Industri Retail. Komisi Pengawas Persaingan Usaha (KPPU).

http://www.kadin.Indonesia.or.id/enm/images/dokumen/KADIN-982832-09052008.pdf.

[14] Wiboonpongse, A., S. Sriboonchitta and Y. Chaovanapoonphol. 2006. Reviews of Knowledge of Informal Labor in Contract Farming and Hired Labor. Health Promotion Plan for Informal Farm Labor Sector. Thai Health Promotion Foundation. 